\title{
Technology Transfer Modalities Utilized by Agricultural Extension Workers in Organic Agriculture in Philippines
}

https://dx.doi.org/10.4314/jae.v23i3.6

\section{Declaro-Ruedas, Mary Yole Apple}

College of Agriculture, Occidental Mindoro State College, San Jose, Occidental Mindoro, Philippines. E-mail Address: tsinelas_yole@yahoo.com, Phone: +63 (908) 896-1782

\section{Abstract}

This study determined the profile of agricultural extension workers in the municipalities of San Jose, Magsaysay, Rizal, and Calintaan (SAMARICA), Occidental Mindoro; their technology transfer modalities utilized in extending organic agriculture; problems encountered in the technology transfer; and the relationship between the profile of the agricultural extension workers and the technology transfer modalities utilized in organic agriculture. The respondents of the study were the 42 front line agricultural extension workers in the Local Government Unit. They were selected using simple random sampling. Mean and the Pearson Moment Correlation were used in data analysis. Result shows the agricultural extension workers in SAMARICA Area, Occidental Mindoro have an average age of 48.76 years, with long extension experience of 18.14 years, and had earned a college degree related to agriculture. They "always" introduce new technologies and practices on organic agriculture with the farmers through individual farm/ home visits, farmers' groups meetings, and use of Information and Communication Technologies (ICT)). The agriculture extension delivery system in SAMARICA Area, Occidental Mindoro is facing challenges in implementing organic agriculture initiatives in the municipal level. Furthermore, agriculture extension workers' age is significantly related to the technology transfer modalities utilized in organic agriculture

Key words: extension workers, extension modalities, knowledge transfer, organic agriculture

\section{Introduction}

Agricultural extension is essentially a message delivery system organized to convey the latest findings of agricultural; research to farmers. Effective communication is therefore, the prime requirement in extension work (Memon et al, 2014). Agricultural extension plays a crucial role in boosting agricultural productivity, increasing food security, improving rural livelihoods, and promoting agriculture as an engine of pro-poor economic growth (IFPRI,nd). Agricultural extension aims at providing farmers with necessary education, skills and technical information to enable them to make effective farm management decisions to enhance their daily practices. Further, it is an effective mechanism and system or services which directly help farmers to help them (FAO, WFP \& IFAD, 2012).

Declaro-Ruedas (2015) reported that the agricultural extension workers in Magsaysay, Occidental Mindoro introduce new technologies and practices on organic agriculture with the farmers through "frequent" group meetings, method demonstration, farmer field 
school, establishment of demo farm, conduct of farm/home visits, and use of information and communication technologies.

The agricultural extension in the Philippines is governed by RA 7160 known as the Local Government Code of1991, which decentralized the extension function, from one central government that would supervise and facilitate agricultural extension and training services for farmers, fishers and other beneficiaries -extension and training activities were passed on to the Local Government Units (LGUs). The LGUs inherited the general agriculture extension. The largest proportion of the country's agricultural extension force is with the LGUs which consist of 79 provinces, 84 cities and 1,525 municipalities and more or less 42,000 barangays. In SAMARICA Area, Occidental Mindoro, the agricultural extension is a public service under the LGU. To understand the scope of the agricultural extension worker (AEW), it can be noted that there are about 225,763 populations, who primarily focus on agriculture, fisheries and agriculture related activities, whereas about 60 AEWs are distributed across these barangays. This shows a small number of AEWs working with a large number of farmers, and fishers. Thus, more AEWs are needed, and they need to become more competent to be able to more effectively contribute to performance improvement of the agri-food sector.

The demand for organic product is increasingly in local and international markets. This provides not only opportunities but also challenges for the development of this sector. The government support for organic agriculture heightened in 2010 in the Philippines with the passing of the RA 10068 or the Organic Agriculture Act of 2010 which stipulates the development and promotion or organic agriculture in the country. However, the results of the Organic Agriculture Baseline survey (OABS) in 2012 indicated that organic agriculture production in the Philippine is minimal (Garcia et al. 2014).

The Organic Agriculture Act of 2010 is a landmark reform initiative for the Philippine's agriculture sector, which address the challenges and issues facing the sector including positively contributing to the over-all growth and development of the country.

With this, the delivery of organic agriculture knowledge and skills to the farmers was primarily cascaded through the extension workers in the different provinces in the country. Thus, there is a need to investigate the technology transfer modalities utilized by the agricultural extension workers in transferring organic agriculture program. The specific objectives were to:

- describe the profile of the LGU agricultural extension workers in SAMARICA, Occidental Mindoro;

- identify the technology transfer modalities utilized by the agricultural extension workers in organic agriculture;

- identify the problems encountered in the technology transfer of organic agriculture; and

- identify the relationship between the profile of the agricultural extension workers and the technology transfer modalities utilized in organic agriculture. 


\section{Hypothesis}

Ho1: There is no relationship between the profile of the agricultural extension workers and the transfer methods utilized in organic agriculture.

\section{Methodology}

The study was conducted in the southern municipalities of Occidental Mindoro, Philippines, namely: San Jose, Magsaysay, Rizal and Calintaan. The province falls within latitude13.1024 ${ }^{\circ} \mathrm{N}$ and longitude $120.7651^{\circ} \mathrm{E}$. The list of extension workers and registered farmers was sought from the Municipal Agricultural Office. The respondents were the $42(73 \%)$ front line agricultural extension workers (AEWs), who work at the Municipal Agricultural Office regardless of tenurial status. The study was conducted from July 2016 to January 2017.

Questionnaire was used to gather the needed information. Part I consisted of the profile of the AEWs, Part II identified the technology transfer modalities utilized by the agricultural extension workers in organic agriculture using a 5-point Likert scale, and lastly, Part III enumerated the problems encountered in the technology transfer of organic agriculture. The instrument was validated by research experts in the Municipal Agricultural Office. Their suggestions and correction were considered in the final production of the questionnaire. Findings from quantitative data about technology transfer methods used were further explored using key informant interview (KII) with the organic farmers, farmertechnicians and municipal agricultural officer. Mean, ranges and Pearson Moment Correlation were used in the study.

Lastly, literature review on the technology transfer methods employed in Asia, in the Philippines and in Occidental Mindoro was done specifically the Compendium on Extension and Technology Transfer Modalities in Agriculture, Fisheries and Natural Resources in the Philippines published by Philippine Council for Agriculture, Aquatic, and Natural Resources Research and Development (PCAARRD), University of the Philippines Los Banos (UPLB), Agricultural Training Institute (ATI), and Philippine Extension and Advisory Services Network Inc. (PhilEASNet).

\section{Results and Discussion}

\section{Profile of Agricultural Extension Workers}

The value of agricultural extension work greatly depends on the availability of extension professionals who are qualified, motivated, committed and responsive to the everchanging social, economic and political environment (Declaro-Ruedas, 2015). Results show the agricultural extension workers had an average age of 48.76 years ranging from 23-62 years. This implies that they were within the middle age and are capable of providing technical assistance in the field.

Moreover, their long work experience as an extension worker with an average of 18.14 years ranging from 2-41 years is believed to equip them with first-hand experience and understanding of the farmers' problems and management constraints. The findings corroborates with the study of Ngaka and Zwane (2017) that majority of extension practitioners in South Africa had over 20 years of work experience in agricultural extension and advisory services. 
Creative Commons User License: CC BY-NC-ND

Abstracted by: EBSCOhost, Electronic Journals Service (EJS),

Google Scholar, Journal Seek, Scientific Commons,

Food and Agricultural Organization (FAO), CABI and Scopus
Journal of Agricultural Extension

Vol. 23 (3) July, 2019

ISSN(e): 24086851; ISSN(Print); 1119944X

http://journal.aesonnigeria.org

http://www.ajol.info/index.php/iae

Email: editorinchief@aesonnigeria.org

The AEWs had undergone formal schooling with specializations in agronomy, agricultural technology, animal husbandry, extension education, crop science and fisheries. The average number of years spent in formal education was 15.03 years.

Table 1: Profile of the agricultural professionals

\begin{tabular}{lccc}
\hline \multicolumn{1}{c}{ Profile } & $\overline{\mathbf{x}}$ & Range & std \\
\hline Age & 48.76 years old & $23-62$ & 10.67 \\
$\begin{array}{l}\text { Number of years spent as extension } \\
\text { worker }\end{array}$ & 18.14 years & $2-41$ & 11.36 \\
$\begin{array}{l}\text { Number of years spent in formal } \\
\text { education }\end{array}$ & 15.03 years & $14-16$ & 1.36 \\
\hline
\end{tabular}

\section{Technology Transfer Modalities Utilized by Agricultural Workers in Organic Agriculture}

The use of information and communication technologies ( $\bar{x}=4.55)$ was "always" utilized in extending organic agriculture technology.

The Training \& Visit system, which includes farm/ home visits ( $\bar{x}=4.52)$, and farmers' group meetings $(\bar{x}=4.52)$ were "always" employed technology transfer modalities. It enjoyed the widest geographical coverage and financing, owing to World Bank patronage. However, this methodology is now losing favour. Two of the main criticisms levelled against it are that it follows a top-down approach, and that it is not sustainable, collapsing as soon as external funding runs out.

These results agree with the study of Declaro-Ruedas (2015) that AEWs introduce new technologies and practices through community leaders, farmer's association officials and local leaders by arranging meetings in the farmer leaders' home. The possible explanation for the utilization of these extension methods by the majority of the respondents is the relatively large number of farmers that agents have to serve, which makes the utilization of individual methods practically impossible.

However, farmer field school (FFS) ( $\bar{x}=4.55)$ and formation of coop/FA groups $(\bar{x}=3.68)$ were frequently" used by the AEWS. The FFS method has demonstrated its usefulness in integrated pest management (IPM) programs, especially in Southeast Asia, mainly because it is environmentally friendly. The main strength of the FFS system is its use of participatory processes for learning and decision-making by farmers, who attend regular training sessions which are led by a facilitator and held in a farmer's field throughout a cropping/breeding season. The main strength of the farmer-to-farmer extension method lies in its use of farmers' indigenous knowledge and the high value that it attaches to their opinions.

The formation of coop/FA groups ( $\bar{x}=3.68)$ is in viable, homogeneous and sustainable groups is a challenge in itself. Furthermore, the technical knowledge of farmers may not reflect the latest developments in agricultural technology, and may encourage the continuation of inappropriate traditional practices. The old problem of weak linkages between research and extension still persists, and it is unlikely that there will be any real participation in research agenda formulation on the part of farmers (many of whom are illiterate).

Mobile phones $(\bar{x}=2.42)$ is "occasionally" used in agriculture, the e-agriculture platform constantly cover these examples. Mobile phones either use voice, text or photos within 
Creative Commons User License: CC BY-NC-ND

Abstracted by: EBSCOhost, Electronic Journals Service (EJS),

Google Scholar, Journal Seek, Scientific Commons,

Food and Agricultural Organization (FAO), CABI and Scopus
Journal of Agricultural Extension

Vol. 23 (3) July, 2019

ISSN(e): 24086851; ISSN(Print); 1119944X

http://journal.aesonnigeria.org

http://www.ajol.info/index.php/iae

Email: editorinchief@aesonnigeria.org

the farmer/extensionists interaction. However, there is a need to formulate the right messages for and with farmers, addressing illiteracy and empowering farmers to use mobile phones can lead to increased adoption of new technologies and improved practices.

The conventional and digital broadcasting (radio) was "never" utilized by the AEWS with a mean of 1.40. Although, radio is a key information source for the most time-sensitive local news and information topics, AEWS do not have the capability to use it as a modality. According to Andrango and Bergtold (2015) found out that radio/TV, state department of agriculture programs, and programs were the least frequently ranked extension teaching methods.

Table 2: Technology transfer modalities utilized by the agricultural extension workers

\begin{tabular}{|c|c|}
\hline Technology transfer modalities & $\bar{x}$ \\
\hline Individual farm/ home visits & 4.52 \\
\hline Farmers' groups meetings & 4.52 \\
\hline Methods/result demonstration & 3.61 \\
\hline Farmer field school (FFS) & 4.29 \\
\hline Establish demonstration plots/farm & 3.45 \\
\hline Formation of coop/groups/FA & 3.68 \\
\hline Use of information, communication and technology (ICT) & 4.55 \\
\hline Print media (leaflets/posters/brochures/comic) & 3.34 \\
\hline Cellular phones & 2.42 \\
\hline Educational video programmers & 2.50 \\
\hline Conventional and Digital Broadcasting ( radio) & 1.40 \\
\hline Integration of modern and indigenous knowledge & 3.26 \\
\hline Overall Mean & 3.46 \\
\hline
\end{tabular}

\section{Problems Encountered in Technology Transfer of Organic Agriculture}

The Agriculture and Fisheries Modernization Act (AFMA) also known as Republic Act 8435, mandates the "provision of training, information and support services by the government and non-government organizations to the agriculture and fisheries sectors to improve the technical, business and social capabilities of farmers and fisherfolks." However, the Local Government Code failed to provide mechanisms for the central government or next higher level of LGU to direct assistance or augment services and facilities assigned to the LGUs.

Generally, the agriculture extension delivery system in SAMARICA Area, Occidental Mindoro, Philippines is facing "highly serious" $(\bar{x}=3.58)$ challenges in implementing organic-based initiatives in the municipal level.

The "not serious" problem encountered by the AEWS in transferring organic agriculture is the lack of extension worker's knowledge on organic agriculture $(\bar{x}=1.54)$. This supports the findings of Declaro-Ruedas and Venturina (2016) that AEWS' organic farming knowledge, environmental, marketing, and cost and benefit aspect were rated "agree." Further, they have "positive" attitude towards organic agriculture. 
Creative Commons User License: CC BY-NC-ND

Abstracted by: EBSCOhost, Electronic Journals Service (EJS),

Google Scholar, Journal Seek, Scientific Commons,

Food and Agricultural Organization (FAO), CABI and Scopus
Journal of Agricultural Extension

Vol. 23 (3) July, 2019

ISSN(e): 24086851; ISSN(Print); 1119944X

http://journal.aesonnigeria.org

http://www.ajol.info/index.php/iae

Email: editorinchief@aesonnigeria.org

The "highly serious problems" were the funding for agricultural services depended on the economic class of the LGUs and interests of local officials $(\bar{x}=4.57)$, lack of infrastructure facilities for OA ( $\bar{x}=4.53)$, and coverage of too many target groups by one agent $(\bar{x}=4.53)$. As per interview with an AEW, "the interest and priorities of each local government official vary, thus, funding for agricultural services depended on the economic class of the LGUs and interests of local officials...the agriculture sectors' priority changes as the poetical leaders also change."

The contradiction of mandates and function with other DA attached agencies of the local agricultural extension systems greatly affects the kind of delivery of service it provides to the farmers and fisherfolks $(\bar{x}=4.54)$. For instance, the Fisheries Code of 1998 (RA 8550) empowered the DA through BFAR to develop cost effective, practical and efficient extension services on a sustained basis to municipal fishers in underdeveloped areas. This is in contradiction to the Local Government Code which provided that direct extension delivery services for farmers and fishermen is the responsibility of Local Government Units. Further, there is also a mismatch of priority programs extended in the local government; there is an existing program on hybridization, mechanization and BT corns that is in contrast with the principles of Organic Law.

The lack of encouragement among OA key players in the academe and private sectors is considered a "highly serious" problem with a mean of 3.64. In the context of the Agricultural Knowledge and Information Systems (AKIS), the devolved extension seems isolated and therefore has a very weak linkage with national and international agricultural research.

The AFMA mandates state universities and colleges (SUCs) to assist in the LGUs extension system by improving their effectiveness and efficiency through capabilitybuilding and complimentary extension activities, such as technical assistance, training of LGU extension personnel, improvement of physical facilities, extension cum research and information support services. While, the private sector contribution is encouraged especially the participation of farmers and fisher folk cooperatives and associations and others in the private sector in the training and other complimentary extension services especially in community organizing, use of participatory approaches, popularization of training materials, regenerative agricultural technologies, agri-business and management skills.

The lack of incentives for career advancement $(\bar{x}=4.53)$ is also a "very highly serious" problem. One of the most common complaints of devolved agricultural extension staff was the limited opportunities for career growth. From stable and promising position, agricultural workers have closed priorities of climbing the career ladder since most of the provincial offices are not connected with the regional and national DA structure. One AEW who will retire soon said that "I have been serving for 25 years as an Agricultural Technologist and still without promotion." 
Table 3: Problems encountered in the technology transfer of organic agriculture

\begin{tabular}{lc}
\multicolumn{1}{c}{ Problems } & $\bar{X}$ \\
\hline The LGU extension service is highly dependent on the Internal Revenue Allotment & 3.64 \\
from the national government. & 3.66 \\
The Local Government Code does not have a specific provision for a functional & 3.62 \\
and support relationship with the Department of Agriculture. & 4.56 \\
There is no local ordinance at supports the OA advocacy. & \\
The local Government Code allows national government programs at the local & 4.54 \\
government levels (mismatch of priorities). & \\
There is a contradiction of mandates and function with other DA attached & 3.64 \\
agencies. & 1.14 \\
Lack of complementation among OA key players in the academe and private & 2.91 \\
sectors. & 4.57 \\
Lack of extension worker's knowledge on organic agriculture. & 3.83 \\
Top-down management. & 4.53 \\
The funding for agricultural services depended on the economic class of the LGUs & 4.53 \\
and interests of local officials. & 2.45 \\
Lack of a functional Municipal Organic Agriculture Board. & 2.36 \\
Lack of infrastructure facilities for OA. & 4.53 \\
Lack of incentives for career advancement. & 2.82 \\
Lack of adequate transportation to reach clienteles. & 3.58 \\
Lack of essential teaching and communication equipment. & Ooverage of too many target groups by one agent. \\
Lack of Subject Matter Specialists. & Onean
\end{tabular}

Legend:0.50-1.50-not serious; 1.51 -2.50- less serious; 2.51 -3.50-moderately serious;3.514.50-highly serious;4.51-5.00-very highly serious

\section{Relationship between Profile and Technology Transfer Modalities Utilized}

Results shows that there were no significant statistical relationships between number of years spent in formal education and the technology transfer modalities utilized in the dissemination of organic agriculture $(r=0.63)$. However, age and number of years spent as extension worker have a significant relationship $(r=0.51)$. with a computed $r$ of 0.627 and 0.509 , respectively and critical $r$ of 0.43 .

Further, Andrango and Bergtold (2015) indicate that older extension agents tend to be more satisfied when using internet and news media to learn information; however, those agents working on extension and research and in the government sector tend to be less satisfied when using news media as they learn new information. On the contrary, extension agents with higher level of education are more likely to be satisfied when using news media. 
Table 4: Relationship between the profile and the technology transfer modalities utilized

\section{Profile of AEWS}

Modalities utilized

\section{Computed $r$}

Age

Number of years spent as extension worker

0.627

0.509

Number of years spent in formal education

${ }^{*} \mathrm{P} \leq 0.05$

\section{Conclusions and Recommendations}

The agricultural extension workers "always" introduce new technologies and practices on organic agriculture to the farmers through individual farm/ home visits, farmers' groups meetings, and use of information and communication technologies (ICT). It was noted that radio broadcasting was "never" utilized, although, radio is a key information source for the most time-sensitive local news and information topics. This may be due to the fact that AEWS do not have the capability to use it as a modality as well as the lack of facilities in the municipality. In addition, the "highly serious" challenges in implementing organic agriculture initiatives in the municipal level were funding dependency of the agricultural services on the economic class of the LGUs and interests of local officials, lack of infrastructure facilities for the implementation of the organic agriculture program, and coverage of too many target groups by one agent.

Thus, there is a need to capacitate the AEWS on the different extension modalities to reach a wider range of farmers. This will also help in the appropriate delivery and effective dissemination of information in organic agriculture in the municipal level.

\section{References}

Andrango, G. and Bergtold, J. (2015). Extension agents' preferences on teaching methods: An ordered probit with selection model. Presented during the 2015 Agricultural \& Applied Economics Association and Western Agricultural Economics Association Annual Meeting on July 26-28, 2015 at San Francisco, CA

Declaro-Ruedas, M. (2015). The agricultural extension workers' attitude toward organic agriculture in Magsaysay, Occidental Mindoro. ISSAAS Book of Abstracts.

Declaro-Ruedas, M. \& Venturina, A. (2016). The extension modalities used by the agricultural professionals and their attitude toward organic agriculture in Occidental Mindoro, Philippines. Presented during the XIV World Congress of Rural Sociology on August 10-14, 2016 at the Ryerson University in Toronto, Ontario, Canada.

International Food Policy Research Institute (IFPRI). (nd). Agricultural Extension. http://www.ifpri.org/topic/agricultural-extension Downloaded 24/04/2019 
Food and Agricultural Organization FAO, WFP \& IFAD. (2012). The State of Food Insecurity in the World 2012. Economic growth is necessary but not sufficient to accelerate reduction of hunger and malnutrition. Rome, FAO.

Garcia,R., Peredo, J., \& Estrada, j., (2014). Towards the establishment of a data system for organic agriculture. http:/ www.nscb.gov.ph/ncs/papers/INVITED/IP Downloaded 24/07/2018

Memon, I., Panhwar, K. , Chandio, R. , Bhutto, A. and Khooharo, A. (2014). Role of Mass Media in Dissemination of Agricultural Technology among the Farmers of Jaffarabad District of Balochistan. Journal of Basic \& Applied Sciences, 2014, 10, 525-531.

Ngaka, M. J., \& Zwane, E. M. (2017). The role of learning networks in agricultural extension service delivery: a survey in the nine provinces of South Africa. South African Journal of Agricultural Extension , 45(2), 26-37. https://dx.doi.org/10.17159/2413-3221/2017/v45n2a398 Downloaded 22/04/2019 